\author{
(c) (1) (8) \\ Jurnal Terapan Manajemen dan Bisnis is licensed under \\ A Creative Commons Attribution-Non_Commercial 4.0 International License.
}

\title{
A BALANCED SCORECARD EXECUTION: A KEY TO SUCCESS FOR A SUSTAINABLE CREDIT UNION
}

\author{
Lianto \\ STIE Widya Dharma, Pontianak, Indonesia \\ E-mail: lianto71@gmail.com
}

\begin{abstract}
The purpose of this essay is to explore and apply the wealth of the Balanced Scorecard framework in the management of credit unions. The effectiveness of this framework has contributed greatly to the business world. The cross functional paradigm in the Balanced Scorecard concept enables stakeholders to review various business activities in a holistic manner. A qualitative approach is used to explore concepts and their applications in business. This study offers a roadmap for credit unions to implement the Balanced Scorecard framework in the context of performance management.
\end{abstract}

Keywords: credit union, balanced scorecard, strategy, key performance indicator

\section{Introduction}

Achieving economic independence is the dream of every person/organization. The presence of Credit Union (CU) in Indonesia has succeeded in alleviating small communities from poverty. As a social business entity, CUs do not only prosper society financially and economically, but also become a community where people learn to give and receive trust. Through social relations in the $\mathrm{CU}$, humans are made aware that by giving, they receive; by trusting, he is trusted. Judging from its history and development, $\mathrm{CU}$, which has been built from a trust pillar, has become a built-to-last and built-to-bless organization.

The main key to the existence, growth, and sustainability of a CU is the trust of the members (customers). CUs that lose members' trust are just waiting to declare bankruptcy. The cornerstone of the CU 'building' is the member. Collin and Porras (2002) found that companies that are built to last place customers in a prime position above other things. This positioning is a key feature of a visionary company. Merck, for example, formulated its core value: "Medicine is for people, profits come later" (Widjaja, 2004). In its Credo, Johnson \& Johnson also places their first responsibility on the interests of customers above the interests of employees, management, the surrounding community and shareholders. To be sustainable, the governance of CU must be focused on the members' satisfaction objectives. All development efforts are from the motives to improve the members' welfare. The problem is how to manage the CU so that activities in it can be directed at member satisfaction? To answer this problem, the Balanced Scorecard concept is presented as an effective framework and directs all operational activities towards the objective. 


\section{Literature Review}

The concept of the Balanced Scorecard (BSC) comes along with a revolutionary transformation from the industrial era to the information age. The transition to the information age in the last few decades has conditioned businesses to create competitive advantages in new ways. A number of keys to success in the past, for example the concept of economies of scale and scope, are no longer the silver bullets in the new era. To achieve competitive advantages, businessmen must be able to develop intangible assets.

At least, there are three main differences between tangible and intangible assets. First, tangible assets are calculated rigidly in financial statements. Conversely, intangible assets are difficult to be priced. No one can give financial value to an innovative culture that creates new products/services that are more qualified than competitors. No one can give value to the good relationship that exists between employees and the customers served. In fact, on the other hand, to obtain such capabilities, the organization incurs costs that are clearly recorded in the financial statements. Second, tangible assets are easily imitated. Conversely, intangible assets are often the result of a combination of complex competencies that are not possible to imitate. A company can build a high building and buy a variety of sophisticated equipment. However, it can be imitated by its competitors. Conversely, the commitment and loyalty of employees created by interpersonal relations for many years is not easy to buy or copy. Third, tangible assets will shrink along with their use, whereas intangible assets will actually develop. The machines and equipment used are increasingly worn out. On the other hand, employee skills and good communication will be increasingly honed and developed. Unfortunately, the value of intangible assets cannot be recorded in the financial statements. Financial statements precisely state the costs incurred to create the asset. This is the main reason for the emergence of the BSC concept. This concept would like to express the causal relationship between costs incurred and the results obtained in the form of intangible assets. The limitations of financial statements to accommodate the benefits of intangible assets remind organizations not to base performance appraisals only on financial performance (Lianto, 2011).

BSC is a strategic management tool that can help organizations to translate strategies into action by utilizing a set of indicators (financial and non-financial) developed in a causal relationship. If a business entity in the past assesses success only from a financial perspective, the BSC offers three new perspectives, namely: learning and growth, internal processes, and customer satisfaction. This concept is the result of a research developed by Robert S. Kaplan and David P. Norton, two professors from Harvard Business School. BSC is one of the many strategic planning methods. Since its emergence in 1992, this concept has quickly caught the attention of the business world amid the hustle and bustle of hundreds of effective business concepts that continuously emerge and sink (Niven, 2003). The preservation of the BSC concept has so far located its relevance in answering three fundamental problems that haunt today's business entities. The three problems are: dominance of intangible assets in the information age, traditional dependence that is exclusive to financial measures, and difficulties in carrying out strategies.

The dominance of intangible assets in the information age is a problem in many companies because intangible assets are difficult to price in financial statements. Development of intangible assets makes certain departments (especially $R$ \& D) receive 'red report cards' in financial statements.

In the BSC, the term causal relationship is widely known. Every perspective in the BSC has a series of strategic objectives. The strategic objectives for each perspective are explained as a causal relationship. This enables this concept to be coherent among growth 
driver variables. With this logic, each strategy actor gets a clear picture of their responsibilities in achieving success and the relevance of each other in the organization as a whole (holistic). Thus, they will try to improve the teamwork, because success in one part influences and is influenced by other parts (Luis and Biromo, 2007). The BSC framework allows organizations to track intangible assets and provide a measure of their changes to get results.

The problem of relying on performance solely on financial objectives is addressed by the BSC by developing a causal relationship and balance between financial objectives (financial perspective) with non-financial objectives (strategic objectives) such as human resource capabilities, information system capabilities, organizational capabilities (learning and growth perspectives); product quality, product innovation, production efficiency (internal process perspective); and customer satisfaction, customer relations, market share, brand image (customer perspective). Causal relationships that place financial objectives as lagging indicator and non-financial objectives as leading indicators open the stakeholders' insight that in order to achieve financial objectives, organizations must carry out nonfinancial objectives.

BSC also answers the problem of many companies' constraints to implement the strategy. As what is usually stated that, the strategy that is not executed is only worth $\$ 1$. Through a set of financial and non-financial key performance indicators (KPI) that are causally intertwined, BSC is an effective tool for translating strategies into action.

To view the organizational performance holistically, BSC offers four perspectives that must be measured equally. The four perspectives are financial, customer, internal processes, and learning and growth. Kaplan and Norton (1996) argued that the four perspectives are sufficient to measure and translate vision and strategy into strategic objectives and initiatives. The more measures, the more information that should be collected. Measuring a few related things is more valuable than measuring a lot of things that are not related or difficult to find the causal links. When a car is running, actually there are hundreds of processes under the hood of the car. However, we don't need all the technical information, unless a serious damage has occurred. A driver simply monitors a number of indicators in the dashboard panel such as speed, fuel consumption, electricity, lubricant, and engine temperature. What is important is that the set of measures that are set is really focused and directly related to the strategy. Citing Charles Handy, Niven (2005: 108) wrote: "measuring more is easy, measuring better is hard." In the context of the CU, BSC's Customer Perspective is understood as a Member Perspective, because customers in CU are members of the CU itself who act as the owners and users of services provided by the $\mathrm{CU}$. The CU's only goal is to serve its members (Munaldus et al., 2012).

Since being born from the Kaplan and Norton's thoughts up to now, BSC has grown tremendously in both its form and application. Stunning statistics are circulating about the application of the BSC in the world of organization: adopted by around $50 \%$ of companies listed on the Fortune 1000, adored as one of the 75 most influential business ideas of the $20^{\text {th }}$ century, and utilized by public, private and non-profit companies (Niven, 2005).

\section{Methodology}

This study was conducted by using a qualitative approach. Extracting the concepts and framework of the Balanced Scorecard was done through intensive literature studies. Unstructured observations and interviews were carried out to understand the ways to work of the CU staff (employees) daily. An inductive analysis was carried out to produce a balanced scorecard-based framework that could be applied by the CU. 


\section{Results and Discussion}

The Framework of Balanced Scorecard for Credit Union

According to the World Council of Credit Union (WOCCU), CU is "not-for-profit cooperative institutions" (Munaldus, 2012: 2). As a non-profit institution, the composition of the four BSC perspectives needs to be modified. In non-profit institutions, the Member Perspective occupies the peak of attention, not the Financial Perspective. This modification is intended to convey the message that all efforts made to develop financial aspects are carried out to support members (Niven, 2003).

The BSC framework that can be applied to Credit Union is presented in Figure 3 containing the following roadmap.

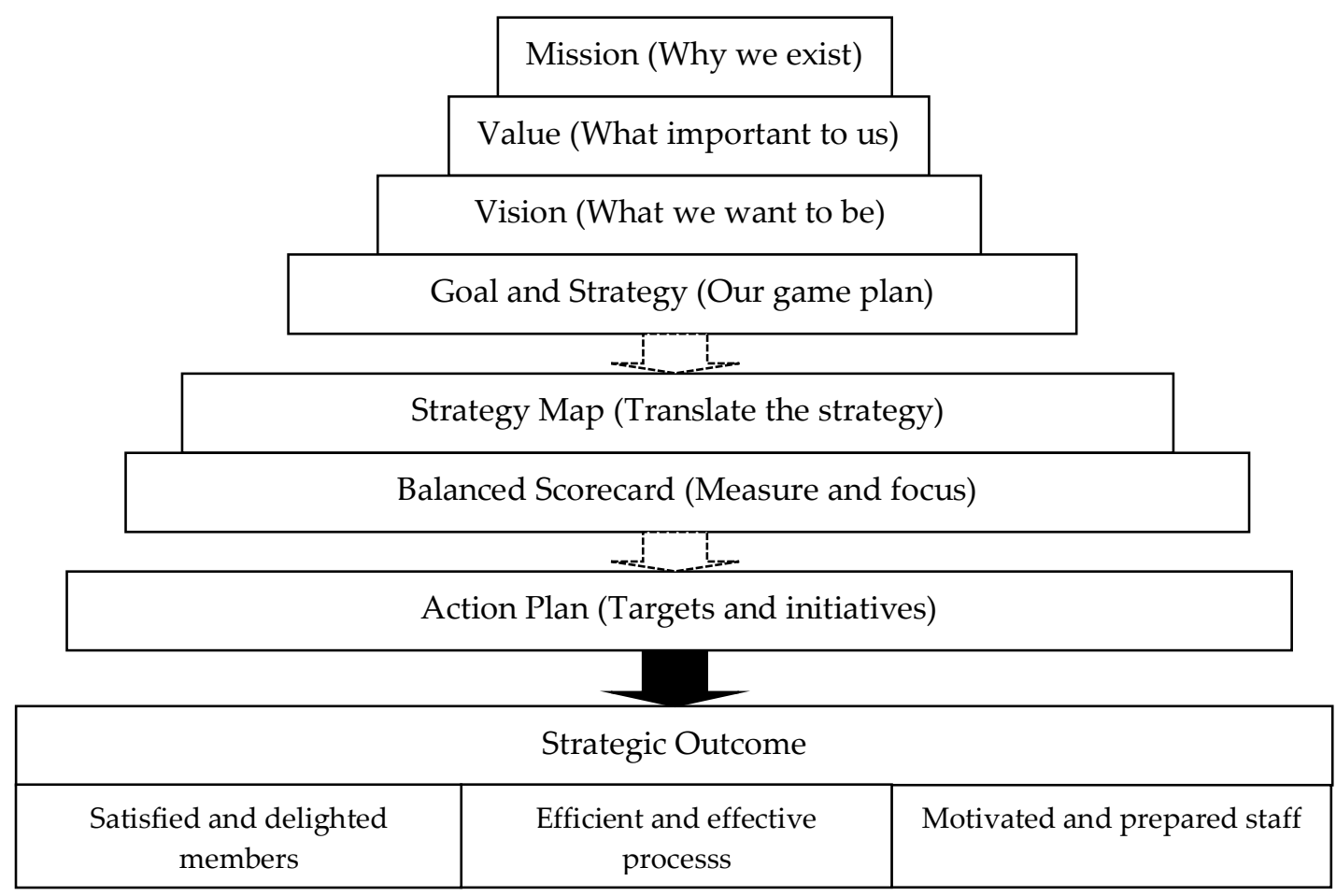

Figure 1 The roadmap of the Balanced Scorecard Implementation

Adapted from Kaplan dan Norton, 2004: 33

The three outputs of the BSC are the strategy map, the four perspective scorecards, and the action plan. Strategy map is a tool that gives an overview of causal relationships in each perspective, how goals are achieved, and aligning employee actions with organizational goals. Scorecard is a measuring tool for setting goals, encouraging strategy implementation, and measuring performance. While the action plan is a plan of concrete actions that are planned to reach the objective (Purnawanto, 2010).

Clarification of Mission, Values, and Vision

According to Drucker (1974), asking "What is our mission?" is the same as the question "What is our business?" In other words, a mission is a declaration of the reason of being an organization. Therefore, to formulate a mission, the organization must ask the question "In what business do we exist or should there be?" All organizations must have 
"reasons for existence", even if strategy planners have not consciously made the reason in written form.

Managers must also strive so that the mission statement does not become too unfeasible, thus so that it cannot be applied. According to David (2013), the mission statement must be more of a statement of attitude and views than a specific detail. The ideal mission statement looks for the midpoint between the specific and the general. Too many specific details can limit the organization's creative growth potential. Conversely, if the formula is too general, it will tend to be blurred and not focused. It is better if the mission statement is not too long. The important thing is: the mission statement can generate positive feelings towards the organization, motivate to act, show the direction and strategy of future growth, and have a dynamic orientation. Effective missions must provide useful criteria in generating, filtering, and choosing alternative strategies. Unlike strategies or goals that can be achieved within a certain time, a mission is never fully achieved. The mission can be seen as a lighthouse, compass, or star that shows the direction of the organization. Complementing the guidelines so that the formulated mission can play an effective role, Niven (2003) offered three criteria, namely inspiring change, reaching a long time, and easily understood and communicated.

Value is a timeless principle which becomes a direction for an organization. Values represent organizational beliefs and are shown through the daily behavior of employees (Niven, 2003). Collins and Porras (2002) defined value as an essential and eternal teaching in the organization, which acts as a guiding direction that does not require external justification. Values held firmly do not compromise the achievement of financial benefits or short-term policies. Values can be expressed in various ways, the important ones are that it is simple, clear, direct, and strong. Visionary organizations usually form three to six items of value.

According to Niven (2003), a vision shows a decisive transition from a fixed and stable mission to a vibrant and dynamic strategy world. A formulation of vision provides an idea of what the organization wants to be in the next 5, 10, or 15 years. Different from the mission, a vision should not be abstract, but must be as concrete as possible so that it can provide the basis for the formulation of objectives and strategies. A strong vision provides a framework for people in the organization so that it is helped to have a clear form of the abstract future in sight. Typical elements in the vision include: coverage of organizational activities, how organizations want to present themselves before the stakeholders, areas of excellence or differentiating competencies, and strong values held. Everyone involved and interested must do everything significant to achieve that vision.

Niven (2003) offered six characteristics that can be considered so that the organization can form an effective vision, namely: concise, pleasing stakeholders, consistent with mission, verifiable, realistic, and inspiring. Despite of the company size, a formulation of a creative vision is very important not only to describe what you want to achieve but also to inspire all employees to work together to face various challenges. Vision can present the most important component because it becomes the channel between the reasons for existence as reflected in the mission and strategies pursued to achieve the future.

\section{A Strategic Analysis: Translation of Goals and Strategies}

A strategic analysis produces two outputs, namely the strategic goals and strategies chosen to achieve these goals. In this stage, the organization reviews and scans the entered situation. Environmental scanning can be done through a SWOT analysis. This analysis allows strategy planners to find the compatibility between opportunities and threats with internal strengths and weaknesses. The analysis of the organization's internal and external conditions in which the organization rests will help the planner to choose a number of 
rational alternative strategies. The choice of the strategy can be clarified after the SWOT matrix (or TOWS) is made with the key idea: USED. USED is an acronym for Use each Strength, Stop each Weakness, Exploit each Opportunity, and Defend each Threat (Morrison, 2016). According to Thompson and Strickland (2001), SWOT analysis is more than just an exercise in making a list of situations. The most valuable part of the SWOT analysis is determining what is conveyed about the company's situation and what actions are needed. To obtain the value from managerial and strategic decision making, SWOT analysis must be the basis of action.

\section{A Strategic Planning: Strategy Maps and Balanced Scorecard}

Strategic planning stages occupy a critical position because at this stage, there will be shown a coherence and balance between the long-term and short-term plans of an organization. This stage is crucial because this is where the organization is guided to the directions that are closer to the real action. In the strategic planning, the Balanced Scorecard provides a framework to translate mission, vision, goals, and strategies into comprehensive and coherent objectives and initiatives. In addition, the logic of the causality of the Balanced Scorecard (in strategy maps) will make strategic objectives and initiatives measurable so that they can be managed and realized (Mulyadi, 2007). The entire output translated by the Balanced Scorecard at this stage includes strategic objectives, strategic measures from the four perspectives, targets, and strategic initiatives (action plans).

\section{Strategy Maps}

What is done in the strategy maps is actually something people usually do when drawing the relationships between a number of key variables in a problem. The advantage of BSC lies in the affirmation of simple things that people usually do to be deepened and given meaning. By making connections from a number of strategic objectives in all four perspectives, instinctively, people will begin to associate one objective with another on the basis of a pattern of causation. By using this, people can, with strong affirmations, realize the need for a training program (for example). It is because by being focused and having an appropriate training, it will enable the human resources to produce higher quality services. The causal image pattern in Strategy Maps also realizes the importance of interdependence and thus, it better formulates unique strategies. When it comes to the discovery of a concept of Strategy Maps, Kaplan and Norton (2004: 13) wrote: "the map has turned out to be as important an innovation as the original Balanced Scorecard itself." With Strategy Maps, the transition of intangible assets to tangible assets becomes clear because of the causal relationship that is mapped from the strategic objective of the Financial perspective to the Member's strategic objective.

What is the number of objectives in Strategy Maps in order to be effective? Niven's (2005) experience in many BSC projects showed that it was easier to formulate more than only a little. When a BSC team negotiates to determine an objective, the output can reach 30 objectives because each part struggles to make its interests included. The objectives that have been formulated are even able to reproduce. This shows a general condition in which people are easier to offer a large number of ordinary ideas than to squeeze the brain to think and sort to produce a few of the right and the most critical objectives with the strategy. There is certainly no magic number that is definitely effective for all organizations. However, from Niven's experience, he expressed the principle that less would be better, as long as it showed little focus that had passed through thoughts in order to find the real strategic objectives. If all things are considered important and need priority, then there is no priority. From here, it is clear that the objectives discussed in the BSC are given a 'strategic' attribute to emphasize that 
the objectives set must be focused on the organization's strategy. The failure of some BSC implementers is caused by excessive targeting. An effective leadership role for sorting priorities becomes an important requirement. As Shiller said in Niven (2005: 83) that "the ability to focus attention on important things is a defining characteristic of intelligence."

\section{The Strategic Objectives of Member Perspective}

Member Perspectives question the status of how employees service the CU members. This focus is in line with the echo of the globalization era which conditions the transformation of sellers' markets into buyers' market (Widjaja, 2004; Lianto, 2011). This makes modern management deepen the philosophy that shows recognition of the importance of customer focus and customer satisfaction (Yuwono, Sukarno, and Ichsan, 2007).

The objective of the Member Perspective is how to make CU have members whose numbers continue to increase from year to year, which can be indicated by the growth of its market share. This market share is the main objective. This objective is supported by what Kaplan and Norton (1996) mentioned as value propositions. The value propositions want to show the attributes provided by the company in its products and services to create loyalty and satisfaction for the members. This value proposition is a key concept for understanding the triggers of satisfaction, acquisition, retention, and market share. In general, three attributes can be stated, namely: product or service, good relationship with members, and image and reputation.

Product/service attributes include the function, quality, and price of the product/service offered. The function refers to benefits perceived by members. The quality can be in a form of responsiveness of services provided. The prices are all costs incurred by members. The members' relationship includes convenience, speed, certainty, reliability, and responsiveness in conveying values to the members. While the image is an intangible factor that attracts members because of adequate human and technological resources. Generally, the strategic objectives in this perspective are member loyalty, satisfaction, acquisition, and retention.

\section{The Strategic Objectives of Internal Process Perspective}

The key activities in the Internal Process perspective are related to the delivery of values to the $\mathrm{CU}$ members. This process is formed by the anatomy of three important steps, namely the stage of creation (innovation), the stage of manufacture, and the stage of aftersales service. These three stages are closely related. The creation stage contains the idea of making innovative products/services tailored to the needs of members. The second stage is the actualization of innovation. The third stage provides space for meeting members' needs through after-sales services. These three processes are often referred to as internal process value chains. The strategic objectives in this perspective can be aimed at developing innovative savings/loan products, improving transaction and administrative services, and developing network members.

\section{The Strategic Objectives of Learning and Growth Perspectives}

This perspective relates to the quality and capability of organizational resources that are developed to trigger the previous perspectives. This perspective is often referred to as the perspective of organizational capacity which is seen as the key to executing established strategies, developing and operating effective processes, ensuring the results of financial management, and involving and satisfying the members. The objective of this perspective must be continually measured and developed. There are three aspects that are interrelated, which determine the direction of the strategic objectives to be formulated. 
First, the human aspects involved in the organization, such as managers and CU employees. They must have the appropriate skills, and are trained, knowledgeable and also have a great desire to fulfill their role in supporting the quality processes that satisfy members. Managers must be able to display effective strategic leadership. Second, the aspects of technology and information systems must be effectively empowered. This aspect is important especially in the current information age. Third, the aspect of intangible assets in the form of organizational capabilities to align all elements of the institution in achieving its goals. This means that all efforts made whether in the form of policies, budgets, modification of savings and loan products, new procedures, dismissal or promotion, or communication with members, must contribute to the improvement of the desired outcome. This aspect is often associated with organizational culture directed at the mission and vision of the organization.

Starting from the three aspects above, three CU strategic objectives can be determined which are included in the human resources empowerment, namely: human resources capability, Information system capability, and organizational capability.

\section{The Strategic Objectives of Financial Perspective}

Different from the three non-financial perspectives, not much can be said for formulating financial objectives especially for non-profit organizations. This happens because the Financial perspective is a lagging or outcomes indicator that is formed from another perspective (leading indicator). The people who work in this section cannot do anything to improve the existing outcomes, except taking notes and calculating them correctly and summarizing them into a useful information. The measurement of the Financial Perspective is determined by considering the conditions entered by the organization in relation to the three stages of the business life cycle, namely: the stages of growth, sustain, and harvest (Kaplan and Norton, 1996). Each stage has different objectives and emphases. Identifying the life cycle stages for an institution can lead to different opinions depending on the perspective on which an institution is seen. However, the grouping of life cycle stages is not a definite sorting. It is often happened that when an institution has many characteristics, thus making it being identified into the harvest stage. Yet, at the same time, it also contains characteristics in the stage of growth.

\section{Balanced Scorecard: Measures and Targets}

"A strategy map without performance measures is a bit like a sailboat without wind - a pleasant diversion but far from its maximum advantage," said Niven (2005: 93). The strategy map communicates the objectives of what should be done well to carry out its strategy. However, to understand how far the objective has been achieved, the $\mathrm{CU}$ requires a set of measures in each perspective to track and evaluate its progress.

Kaplan and Norton (2008: 84) always repeat that "If you cannot measure it, you cannot improve it" in each book he writes. If an organization wants to develop their customer relationship management, innovation and operational processes, and intangible assets (human, system, and culture), the organization needs to integrate the measurement of these three things into its management system. Strategic objectives and strategy maps do clarify (in words and images) of organizational objectives to convey the short and long-term performance. However, organizations still need a set of measures to make those objectives meaningful and can be followed up.

What is the effective size? BSC analogy as a dashboard can be rethought. The same also applies for the CUs where the leader's task is to monitor indicators of success (key) that 
are truly critical and strategic. What is important is that the set of measures that are set is really focused and directly related to the strategy.

\section{The Indicators of Member Perspective}

As in the objective determination of the Member Perspective, the formulation of the Key Performance Indicator here also utilizes the member value proposition. The value indicators for the members are measured by the service quality and member satisfaction. According to ACCESS's auditor guidelines (AACCU, 2009), product/service quality indicators include: product/service goals, product presentations, financial product ranges, mindset about branding, wealth-building products, ability-based loans, access and convenience, value selling, marketing and promotion, stimulating loyalty, and packaging products. While the member satisfaction indicators include: member knowledge, good relations, satisfaction evaluation, share of wallet, excellent service, member benefits, annual meetings, member participation, use of wealth-building products, loan product usage, understanding of negligent loan responsibilities, physical infrastructure, technology infrastructure, computer applications, websites, and database management.

\section{The Indicators of Internal Process Perspective}

To determine the performance measures for the Internal Process perspective, ACCESS offers indicators of operational efficiency and competitive positions. Operational efficiency includes comprehensive operational manuals, procedure manuals, staff productivity, error management, presentation of loan-deposit-withdrawal services, use of machinery and office equipment, and internal communication. While competing positions include strategic direction (clarity of vision, courage of vision, mission formulation, core values, breadth of goals, strategic goals, and annual business plan), image (culture of selling, involvement of local communities, partnerships and cooperation, and relations with national federations), market penetration (user community, age segmentation, member diversity, and gender equality), and compliance with regulations (rules of management obligations and commitments under the law).

\section{The Indicators of Learning and Growth Perspective}

Learning and Growth perspective indicators provide an infrastructure to achieve the objectives of the other three BSC perspectives, and are a driver to achieve good results while at the same time encouraging companies to become Learning Organizations and trigger their growth (Kaplan and Norton, 1996). In the context of accreditation, ACCESS outlines key indicators on this perspective including leadership and staff satisfaction. Leadership is viewed from the central elements of key decision making, functions as advisors, service, guardian functions, symbolic, composition and commitment, guidance and direction, rules, performance evaluation, and leadership gender equality. While staff satisfaction includes the administration (work design, selection and recruitment, compensation, and staffing levels), performance management (performance goals, assessment standards, performance as shared values, and team capabilities), and insight management (career paths and development programs).

\section{The Indicators of Financial Perspective}

Even though it is not sufficient if it is used as a single benchmark, the Financial perspective still cannot be abandoned. Kaplan and Norton (1996) still took the Financial perspective into account because financial measures remain important in providing a summary of the consequences of economic actions that have been taken. Whether it is a 
profit-oriented organization or a non-profit organization, the Financial perspective still deserves an attention because it requires good financial performance to manage the organization.

The objectives of the $\mathrm{CU}$ Financial perspective must be measured by relevant measures. ACCESS provides a strategic objective which comes from the goals for protection (measuring negligent loan provisions over 12 months and 1-12 months), effectiveness of financial structures, asset quality, level of income and costs, and signs of growth.

\section{The Formulation of Targets}

The desired target or outcome of a measure plays a role in strengthening the meaning of the measures set by the BSC. With the existence of the targets, BSC goes further than simply translating strategies into concrete indicators. It also enables the BSC to really provide the information about performance. Only if an organization considers performance based on the desired results, then important information is generated. According to Yuwono, Sukarno, and Ichsan (2007), targets are very important for organizations in order to communicate to employees what they want to achieve. Targets also show the commitment that must be held, both by the management and employees to achieve what was planned. Targets can also be the basis of performance appraisal, motivation for employees, and to offer challenges for improving employee performance.

Determining targets is far more difficult than it seems (only a percentage of what you want to achieve). It turns out that the great benefits contained in it must be paid with the same level of difficulty. Kaplan and Norton (2008) themselves admitted that this part is a difficult stage. The difficulty is caused by gaps which are often found between aspirations and reality. On one hand, targets are set by referring to a vision of the future which is usually formulated with ambitious and high objectives. On the other hand, the current reality (status quo) is certainly different. The challenge faced is how to set the targets that can close the gap between future dreams and current reality.

In addition, one thing that is also important is that the targets set cannot stand alone. All targets in each strategic objective must have a causal logic (Kaplan and Norton, 2008). The causal relationship is arranged to enable what is impossible. For example, the CU sets a target of increasing return on capital employed (ROCE) by $20 \%$ for the next three years. Managers can judge that this target is not realistic, considering the rhythm of the achievements of the previous years. However, if the $\mathrm{CU}$ can arrange a causal combination between lagging (yield) and leading (trigger) indicators as required in the Balanced Scorecard, that target might be achieved. The challenge is to make an appropriate mix of targets to allow what is initially impossible. If the target mix made for each perspective is causally related, the CU can assume that a 5\% increase in employee satisfaction will encourage improvement of the service level by $10 \%$. The improvement will further increase the $6 \%$ satisfaction level of CU members, which will eventually trigger a 5\% ROCE increase in the first year. Thus, at the end of the third year, a target of $20 \%$ ROCE will be achieved. After creating and assessing several different scenarios, the $\mathrm{CU}$ can find one scenario with the right combination.

\section{The Formulation of Strategic Initiatives (Action Plan)}

According to Kaplan and Norton (2008), strategic initiatives are a collection of projects and programs outside of the daily operational activities designed to help organizations achieving the targeted performance. Previously, it has been described on how to translate strategies into goals, objectives, measurements, and targets that show what you want to do. Strategic initiatives show how these things are achieved. Just like targeting, in choosing strategic initiatives, it is important to also pay attention to its integration in each 
strategic objective. In other words, the initiative from the objective of the four perspectives must not stand alone, but it must form an integral causal relationship. Each non-financial objective has at least one initiative that triggers the achievement of the relevant objective, and at the same time, it is within the framework of achieving an integrated portfolio.

In a packet of a jigsaw puzzle Balanced Scorecard, strategic initiatives are the last piece to be installed. The target previously described is the tip of reasoning for the performance measures. In order to achieve the target, organizations need to determine what investment initiatives are needed to guarantee positive results (Niven, 2002). To make the initiative choices ensure the achievement of integrated objectives, a number of the following steps deserve an attention (Niven, 2002; 2005).

1. Develop a list of existing initiatives. First of all, the projects and programs that are currently being carried out must be collected. The CU must document everything and based on information, determine which projects only waste resources and which ones are truly strategic (bringing the organization to the objectives).

2. Map the initiatives with strategic objectives. The role, goals, scope, duration, anticipated benefits, and strategic costs contained in every initiative must be understood. This understanding is the basis for determining which initiatives provide important support for objectives in strategy maps.

3. Eliminate initiatives that are not strategic and develop the lost initiatives. This stage requires a diplomatic expertise so that the team members can sincerely accept the initiative they proposed to be decided as a "not strategic" initiative. In this stage, unlisted initiatives are sought and developed but they need to be submitted to support the value creation as a result of strategy maps.

4. Prioritize strategic initiatives. To determine which ones are prioritized, organizations can weigh to see the extent to which certain initiatives are important for the strategy, while still taking the cost factors, net present value, and time projected into accounts to implement them.

\section{Conclusion}

Based on these amounts of performance evaluation methods known in the performance management, the BSC framework as outlined above has a number of advantages that can be underlined. First, the BSC offers a holistic framework. The dependence on financial performance is only enriched by taking the non-financial perspectives into account. Different from a financial perspective, all three non-financial perspectives are feasible to the action plans level. This makes the organization easier to connect the strategic planning and implementation. Second, because of the BSC, a series of strategic objectives becomes more coherent because they are connected with a causal relationship. Third, BSC explains the relationship between goals and achieving goals in a balanced manner. All goals are balanced in order to produce a sustainable financial performance. Fourth, BSC directs strategic planners to determine measurable key performance indicators (KPI). This makes it easy for organizations to achieve their strategic objectives. If we can measure it, we can achieve it.

\section{References}

Association of Asian Confederation of Credit Unions (AACCU). (2009). ACCESS: A-one Competitive Choice for Excellence in Service and Soundness. Alih bahasa: Munaldus. Pontianak.

Collins, J. and Porras, J.I. (2002) Built to Last: Successful Habits of Visionary Companies. New York: Harper Collins. 
David, F.R. (2013). Strategic Management: Concepts and Cases. Harlow: Pearson.

Drucker, P.F. (1974). Management: Tasks, Responsibilities, and Practices. New York: Harper \& Row.

Kaplan, R.S. and Norton, D.P. (1996). The Balanced Scorecard: Translating Strategy into Action. Boston: Harvard Business School Press, 1996.

Kaplan, R.S. and Norton, D.P. (2004). Strategy Maps: Converting Intangible Assets into Tangible Outcomes. Boston: Harvard Business School Press.

Kaplan, R.S. and Norton, D.P. (2008). The Execution Premium: Linking Strategy to Operations for Competitive Advantage. Boston: Harvard Business School Press.

Lianto. (2011). Keunggulan Balanced Scorecard sebagai Sistem Manajemen Strategis yang Holistik. Mabis, Vol. 3, No. 2, pp. 1-18.

Luis, S. and Biromo, P.A. (2007). Step by Step in Cascading Balanced Scorecard to Functional Scorecards. Jakarta: Gramedia.

Morrison, M. (2016). SWOT Analysis (TOWS matrix) made simple. https://rapidbi.com/SWOTanalysis/

Mulyadi. (2007). Sistem Terpadu Pengelolaan Kinerja Personel Berbasis Balanced Scorecard. Yogyakarta: STIM YKPN.

Munaldus, Karlena, Y., Yohanes R.J., Saniansah, and Hendi, B. (2012). Credit Union: Kendaraan Menuju Kemakmuran: Praktik Bisnis Sosial Model Indonesia, Editor: A.M. Lilik Agung. Jakarta: Elex Media Komputindo.

Niven, P.R. (2002). Balanced Scorecard Step-by-Step: Maximizing Performance and Maintaining Results. New York: John Wiley \& Sons.

Niven, P.R. (2003). Balanced Scorecard Step-by-Step for Government and Nonprofit Agencies. New York: John Wiley \& Sons.

Niven, P.R. (2005). Balanced Scorecard Diagnostics: Maintaining Maximum Performance. New York: John Wiley \& Sons.

Purnawanto, B. (2010). Manajemen SDM Berbasis Proses: Pola Pikir Baru Mengelola SDM pada Era Knowledge Economy. Jakarta: Grasindo.

Thompson, A.A., and Strickland, A.J. (2001). Crafting and Executing Strategy: Text and Readings. New York: McGraw-Hill.

Widjaja, R.B. (2004). A Market-Driven Corporate Strategy: Solusi Holistis untuk Tantangan dan Peluang Masa Depan. Jakarta: Tira Pustaka.

Yuwono, S., Sukarno, E., and Ichsan, M. (2007). Petunjuk Praktis Penyusunan Balanced Scorecard: Menuju Organisasi yang Berfokus pada Strategi. Jakarta: Gramedia. 